\title{
Review
}

\section{Biological, Neuroimaging, and Neurophysiological Markers in Frontotemporal Dementia: Three Faces of the Same Coin}

\author{
Barbara Borroni $^{\mathrm{a}, *}$, Alberto Benussi ${ }^{\mathrm{a}}$, Enrico Premi ${ }^{\mathrm{a}}$, Antonella Alberici ${ }^{\mathrm{a}}$, Elena Marcello ${ }^{\mathrm{b}}$, \\ Fabrizio Gardoni $^{\mathrm{b}}$, Monica Di Luca ${ }^{\mathrm{b}}$ and Alessandro Padovani ${ }^{\mathrm{a}}$ \\ ${ }^{a}$ Department of Clinical and Experimental Sciences, Neurology Unit, University of Brescia, Brescia, Italy \\ ${ }^{\mathrm{b}}$ Department of Pharmacological and Biomolecular Sciences, University of Milan, Milan, Italy
}

Accepted 6 September 2017

\begin{abstract}
Frontotemporal dementia (FTD) is a heterogeneous clinical, genetic, and neuropathological disorder. Clinical diagnosis and prediction of neuropathological substrates are hampered by heterogeneous pictures. Diagnostic markers are key in clinical trials to differentiate FTD from other neurodegenerative dementias. In the same view, identifying the neuropathological hallmarks of the disease is key in light of future disease-modifying treatments. The aim of the present review is to unravel the progress in biomarker discovery, discussing the potential applications of available biological, imaging, and neurophysiological markers.
\end{abstract}

Keywords: Biomarkers, cerebrospinal fluid, frontotemporal lobar degeneration, neuroimaging, transcranial magnetic stimulation

\section{INTRODUCTION}

Frontotemporal dementia (FTD) is a genetically and pathologically heterogeneous clinical syndrome characterized by progressive deficits in behavior, executive functions, and language, associated with frontal and temporal lobe degeneration [1-4]. FTD is the second most common cause of dementia in the presenile age group ( $<65$ years of age), and accounts for $5-15 \%$ of all cases of dementia, with a prevalence of 3-26 per 100,000 subjects in the age group of $45-65$ years $[5,6]$.

\footnotetext{
*Correspondence to: Barbara Borroni, MD, Clinica Neurologica, Università degli Studi di Brescia, P.le Spedali Civili 1, 25123, Brescia, Italy. Tel.: +39 0303995632; E-mail: bborroni@ inwind.it.
}

Current redefined clinical criteria identify distinct phenotypes on the basis of presenting clinical symptoms; these include the behavioral variant of FTD, the agrammatic variant of primary progressive aphasia and the semantic variant of primary progressive aphasia [7-9]. In addition, some patients have an associated parkinsonism, as in progressive supranuclear palsy (PSP) and corticobasal syndrome, or motor neuron disease (FTD-MND) [10-12].

Clinical FTD is associated with different types of underlying neuropathology, and the term frontotemporal lobar degeneration (FTLD), characterized by the relative selective degeneration of the frontal and temporal lobes, is used to describe the pathological hallmarks of the disease. Abnormal intracellular inclusions containing Tau, TDP-43, or FUS protein 
have been identified in the majority of cases; however, the correlation between clinical syndrome and underlying neuropathology remains still largely unsatisfactory. Except for nearly $30 \%$ of familial cases, accounted predominantly by the microtubuleassociated protein tau (MAPT), granulin (GRN), and the hexanucleotide repeat expansion of the chromosome 9 open-reading-frame 72 (C9orf72), it is still challenging to predict the underlying pathological process in vivo [13]. Furthermore, because of the possible overlap of FTD with psychiatric disorders or other neurodegenerative diseases, such as early onset Alzheimer's disease or atypical parkinsonisms, diagnosis is often challenging $[14,15]$.

Taking into account these drawbacks, in recent years numerous studies have made significant progress in understanding the pathophysiology and the progression of FTD from a multidimensional approach. Indeed, biological, imaging, and neurophysiological markers have shed light on the very first alterations in the presymptomatic phases of disease [16-21], or to predict disease prognosis [22-24].

With the development of candidate therapies for FTD likely to occur in the coming years, it is of great importance to develop and validate reliable diagnostic and prognostic biomarkers, with numerous implications regarding stratification for disease-modifying clinical trials and for monitoring disease progression.

The objective of the present work is to review and evaluate available literature data in order to highlight recent advances in biological, imaging, and neurophysiological, markers for the diagnosis and prognosis of FTD.

\section{BIOLOGICAL MARKERS: LOOKING AT PROTEIN-OPATHIES}

Looking at biomarkers able to differentiate FTD from other neurodegenerative dementias is one of the hot issues in the current literature, concerning specific therapeutic strategies targeting either TDP-43 or tau accumulations. If neuropathology is clearly predictable in monogenic FTD, in the other cases there is no correspondence between clinical features and neuropathological findings $[25,26]$.

One of the most comprehensively validated series of biomarkers, which reflect the pathological hallmarks of Alzheimer' disease (AD), comprises cerebrospinal fluid (CSF) total-Tau (tTau), phosho$\mathrm{Tau}_{181}$ (pTau), and amyloid- $\beta_{1-42}\left(\mathrm{~A} \beta_{1-42}\right)$. An increase in CSF tTau and pTau, and a decrease in $\mathrm{A} \beta_{1-42}$ (and thus an increased tTau or $\mathrm{pTau} / \mathrm{A} \beta_{1-42}$ ratio), have been shown to identify $A D$ pathology with extremely high accuracy [27], excluding AD in the diagnostic work-up of FTD. These findings have been confirmed both in clinical and pathological cohorts [28-30] and may be particularly useful for excluding focal variants of $\mathrm{AD}$, which may be clinically indistinguishable from FTLD [31-34].

A number of studies have focused on either CSF Tau or TDP-43 metabolism to identify diagnostic markers in FTD patients. Indeed, CSF tTau, pTau, or TDP-43 dosages did not yield convincing results in predicting neuropathological hallmarks $[35,36]$.

A more recent study by $\mathrm{Hu}$ and colleagues has identified in the CSF pTau/tTau ratio a viable biomarker to identify FTLD with TDP-43 pathology as compared to FTLD-Tau [19]. In this view, $\mathrm{pTau} / \mathrm{tTau}$ ratio has been proposed as useful in detecting patients with amyotrophic lateral sclerosis, which is associated with TDP neuropathology [20].

Later, this result was further corroborated in patients with known Tau or TDP-43 pathology, with high accuracy values in identifying TDP-43 cases [20, 21] (Fig. 1) and with prognostic significance [37].

The pathological mechanism leading to reduced CSF pTau/tTau ratio in TDP-43 cases is currently unknown but could possibly be explained by a more extensive neuronal damage leading to increased tTau levels, due to the concomitant inclusions of patients with FTD-MND [19, 21, 37]. This hypothesis could also be supported by the association between a reduced pTau/tTau ratio and survival in patients with FTD [37].

Another approach to identify TDP-43 pathology was to directly measure levels of phosphorylated TDP-43 (pTDP-43) aggregates in blood or CSF. Significantly increased levels of CSF and plasma pTDP-43 have been found in small cohorts of patients with $C 9$ orf 72 or GRN mutations [38]. However, in a pathology-proven cohort, pTDP-43 levels did not differ between FTLD-tau or FTLD-TDP [31]. The quantification of CSF pTDP-43 still needs further refinement to overcome technical issues, as the relatively low concentrations of pTDP-43 in CSF with possibly different isoforms, and the presence of various antibodies that recognize different epitopes and thus vary in diagnostic accuracy [31, 32].

Intriguing results have been obtained by qualitative analysis of CSF Tau protein instead of quantitative evaluation. If CSF total Tau or CSF phospho$\mathrm{Tau}_{181}$ dosages were not able to identify different 


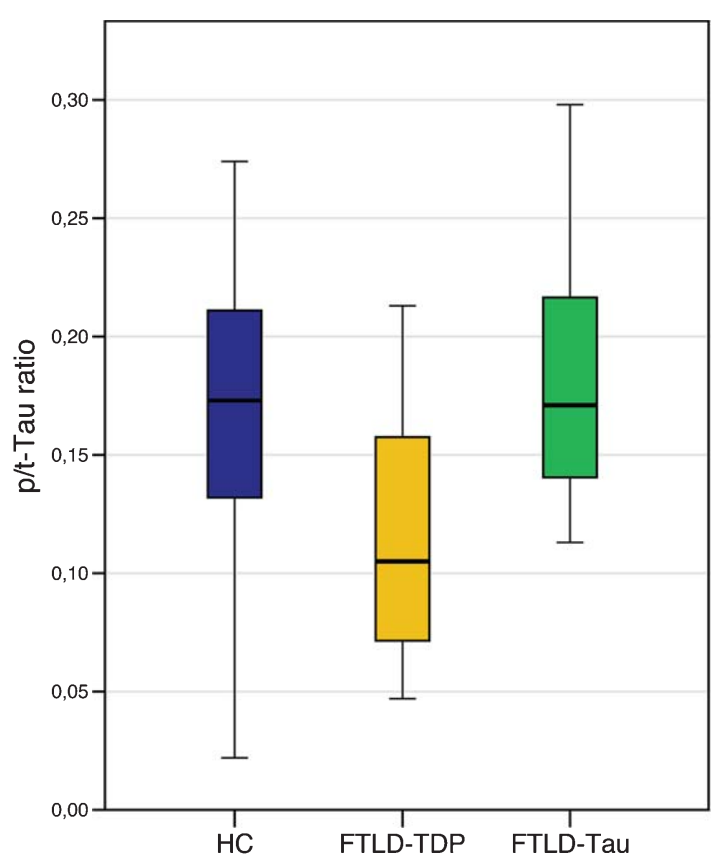

Fig. 1. Levels of CSF phospho Tau/total Tau $(\mathrm{p} / \mathrm{t})$ ratio in FTLD-TDP and FTLD-Tau, compared to healthy controls (HC). Horizontal thick lines illustrate median cerebrospinal fluid (CSF) values, notches correspond to interquartile range, error bars depict 25th to 75th percentile range of data. HC: age-matched healthy controls; FTLD-TPD: including patients carrying a GRN mutation, TARDBP mutations, C9orf72 mutations and patients with FTD-motor neuron disease; FTLD-Tau: including clinically diagnosed progressive supranuclear palsy (PSP) and patients carrying a MAPT mutation.

neuropathological signatures, the assessment of posttranslational modifications of Tau protein in CSF yielded more convincing findings.

Post-translational modifications of Tau protein have been demonstrated to be crucial in FTLD-Tau pathogenesis [39]. However, while the phosphorylation mechanism has been studied extensively, proteolytic processing has received less attention. Literature data reported that different Tau fragments, produced by endogenous proteases, may modulate Tau aggregation itself [40, 41]. Accordingly, the measure of CSF Tau proteolytic forms has been demonstrated to be specifically altered in patients with Tau pathology, namely in PSP cases. CSF Tau isoforms ratio in PSP was 50\% lower than in patients with either neurodegenerative parkinsonism [42, 43] or other Tau-related dementias such as Alzheimer's disease [44].

Accordingly, a previous autopsy study demonstrated that Tau-related pathologies undergo a different Tau proteolytic processing, generating distinguishable deposits of cleaved Tau fragments in PSP brains [45], and explaining biological differences among Tauopathies in CSF. More recently, neurofilament light chain (NfL) has been proposed as diagnostic and prognostic marker in FTD [46]. Neurofilaments are the major components of the neural and axonal cytoskeleton and perform a fundamental role in axonal transport and in synapse functioning, and $\mathrm{NfL}$ is one of the most abundant subunits which increases after neuronal death and axonal degeneration [41].

NfL blood and CSF levels have been shown to be considerably increased in FTD patients compared to healthy controls, being significantly associated with disease severity and survival, and correlating with decreased gray and white matter volume in FTD-associated regions in the frontal and temporal lobes [37, 46-49]. No difference in NfL levels were observed between the different FTD endophenotypes, whereas markedly increased levels have been observed in FTD-MND [37, 46-49]. In presymptomatic carriers, CSF and blood NfL levels have been shown to be within normal range, with a distinct increase after conversion to the symptomatic stage [46]. Whereas some studies showed elevated levels in FTD compared to AD [49], others did not reveal group differences [48]. Furthermore, NfL levels have been shown to be increased in patients with multiple system atrophy, PSP, corticobasal syndrome, and vascular dementia $[47,50,51]$.

As other CSF biomarkers reported above, also NfL levels could possibly discriminate between FTLDTDP and FTLD-Tau, resulting increased in patients with TDP-43 pathology [37, 49]. However, this difference could be accounted for the co-occurrence of FTD-MND in the TDP-43 cohort.

NfL could become a promising, non-invasive biomarker for disease staging, and the strong correlation between CSF and plasma levels [46] makes it even more appealing for monitoring disease progression and treatment response.

\section{NEUROIMAGING MARKERS: LOOKING AT CONNECT-OPATHIES}

In the last three decades, neuroimaging techniques have shown a tremendous development, and have been suggested as powerful tools to elucidate disease mechanisms, track disease progression and explore neuroanatomical correlates of clinical and genetic characteristics [52]. Considering FTD, magnetic 
resonance imaging (MRI) has been widely used for in vivo visualization of brain atrophy in the different clinical phenotypes of FTD, clearly reporting abnormalities in frontal and temporal grey matter regions and related white matter bundles [53-55]. As biomarkers of the underlying neurodegenerative process, these structural perturbations have been used to study the pattern of damage in the sporadic and monogenic forms of FTD [56-58] also tracking disease severity and progression [59-62]. The visual assessment of grey matter atrophy on MRI scans through a series of visual rating scales has been described as a fast, clinical reliable and inexpensive approach to increase diagnostic accuracy in the everyday practice $[63,64]$. Interestingly, structural damage (in particular grey matter atrophy) has been considered as an effective biomarker for FTD not only when the disease is overt [65], but also in the presymptomatic stage, years before clinical onset $[18,66]$. More recently, several neuroimaging approaches for the study of functional connectivity have been applied to FTD, studying coherent patterns of activation among brain regions, in particular at rest [67]. Spontaneous blood-oxygenation level dependent (BOLD) fluctuations, in the context of functional brain networks, have been adopted as sensible and specific biomarkers reflecting connectivity changes early in the disease course, even before structural alterations are detectable with conventional MRI at singlesubject level [16, 68-70]. In contrast with AD, which shows a peculiar involvement of the default mode network, FTD is characterized by a predominant breakdown of anterior functional networks, in particular the salience network [71]. Altogether, FTD functional connectivity approaches have shown a progressive functional network disruption [72-74], both at the regional level [69] as well as the whole-brain level $[75,76]$ using graph-theory measures. In line with these findings, in presymptomatic FTD functional connectivity perturbations (primarily involving salience, frontoparietal, and executive networks) were detectable years before the clinical onset, opening the road for the utilization of these indexes as preclinical biomarkers [16, 68-70]. However, the definition of which markers, i.e., either structural or functional, and which approach are best to track the disease and to assess the response to disease modifying therapies remain challenging. Just recently, Premi et al. adopted a machine-learning approach with multivariate analysis (multi-voxel pattern analysis, MVPA) to different structural and functional MRI metrics in order to study Granulin-related disease, from presymptomatic carriers to symptomatic patients with the same mutation GRN mutation) (Fig. 2) [77]. Working as a classifier, MVPA was able to maximize, for each considered MRI measure, the separation between $G R N$ carriers and controls, in both preclinical and clinical phases of disease. Interestingly, structural measures of grey and white matter atrophy represented the best neuroimaging biomarkers in the symptomatic stage, followed by functional connectivity indexes, in particular regional index like fractional amplitude of low frequency fluctuation (fALFF). On the contrary, in the presymptomatic phase, functional connectivity measures (regional indexes like fALFF and degree centrality) showed the best diagnostic accuracy for still asymptomatic $G R N$ mutation carriers, probably capturing the initial disruption of local signal integration [78, 79]. Altogether, considering a global accuracy $>80 \%$ for either preclinical and clinical phases, fALFF could be considered the best MRI biomarker in the $G R N$ disease continuum [77]. From this point of view, different MRI biomarkers could be defined and applied in the FTD spectrum, in particular with regard to disease-modifying treatments. However, considering future international multicenter clinical trials, a potential MRI biomarker (like fALFF, network and graph-theory indexes) should also prove to be reliable and reproducible, regardless of differences in MRI protocols and acquisition parameters [76].

Besides MRI, also molecular imaging, like positron emission tomography (PET), has been applied in FTD. The evaluation of metabolic brain alterations by fludeoxyglucose $\left({ }^{18} \mathrm{~F}\right)$ tracer provided additional clues into the study of FTD, demonstrating a substantial concordance between cortical atrophy and reduced metabolism [80, 81], with different patterns of damage considering the different clinical phenotypes $[82,83]$. Moreover, the visual evaluation of FDG-PET images provided greater diagnostic accuracy in differentiating FTD from other dementias [84]; more recently, this single-subject approach has been standardized using an optimized statistical parametric mapping (SPM) [85]. However, the most attractive aspect of molecular imaging relies on the availability of PET radiotracers to identify different proteinopathies in FTD [86]. In the last years, specific tracers for Tau pathology have been developed [86, 87]. At the moment, different Tau tracers are commercially available, i.e., $\left[{ }^{18} \mathrm{~F}\right] \mathrm{AV}-1451$ [88] and $\left[{ }^{11} \mathrm{C}\right] \mathrm{PBB} 3$ [89], with different affinity for neurofibrillary tangles and for Tau isoforms ( $3 \mathrm{R}$ and 4R) [86]. Considering FTD, PET Tau imaging has 


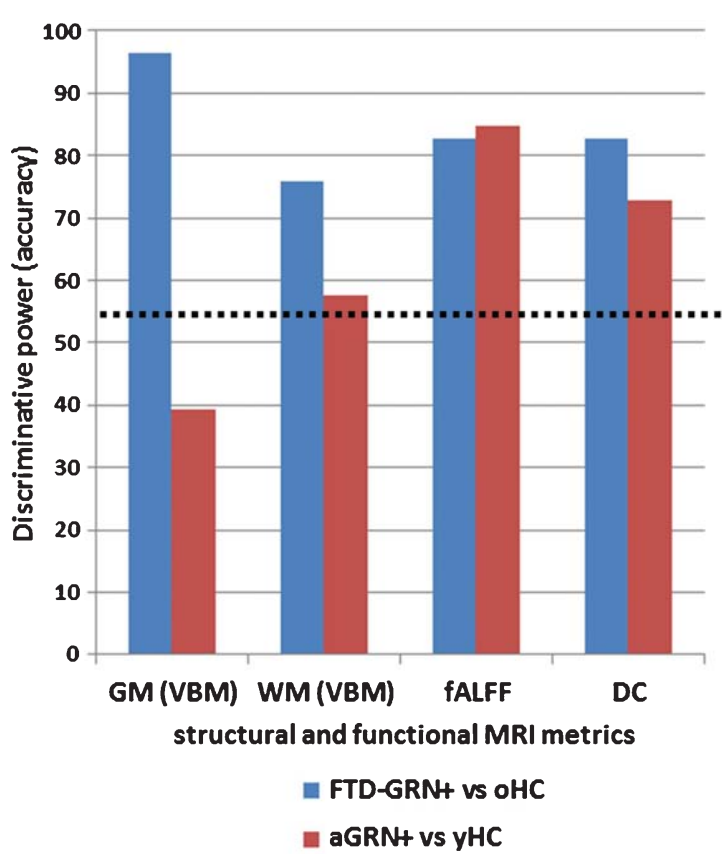

Fig. 2. Bar chart showing the classification results (discriminative power) of the different structural and functional measures. The black dotted line represents the significant $(>55 \%$ of right classification) performance for each measure. Blue is for FTD$G R N+$ versus $\mathrm{OHC}$ and red is for $a G R N+$ versus yHC. FTD- $G R N+$, frontotemporal dementia carrying Granulin mutation; $a G R N+$, asymptomatic carriers of Granulin mutation; oHC, old healthy controls; yHC, young healthy controls; GM, grey matter; WM, white matter; VBM, voxel based morphometry; fALFF, fractional amplitude of low frequency fluctuations; DC, degree centrality.

been recently applied in FTD patients with MAPT mutations (and thus with a known Tau pathology), demonstrating an increased Tau binding in temporal poles and frontal lobes [90, 91]. Interestingly, PET amyloid tracers (like ${ }^{11} \mathrm{C}$-Pittsburgh compound $\mathrm{B}$ or Florbetapir) can aid in the differential diagnosis between FTD and AD, ruling out $A \beta$ pathology [92].

\section{NEUROPHYSIOLOGICAL MARKERS: LOOKING AT NEUROTRANSMITTER- OPATHIES}

Several neurophysiological techniques have been implemented for the study of FTD and the historical initial reports on the use of electroencephalography (EEG) did not identify significant changes in patients with FTD, as opposed to patients with AD [93-95]. Subsequent reports using quantitative EEG (qEEG), showed that the typical qEEG pattern for FTD patients was characterized by a decrease in all of the fast activities $(\alpha, \beta 1-\beta 3)$ relative to healthy controls, but did not differ in slow activities ( $\delta$ and $\theta$ rhythms), possibly reflecting the degeneration of frontal regions in FTD patients [96-98]. Compared to AD patients, FTD showed a diffuse higher $\theta$ power and a decreased $\alpha 2$ and $\beta 1$ values in central/temporal regions $[99,100]$.

Moreover, EEG microstates, which are subsecond $(60-120 \mathrm{~ms})$ periods of stable brain state that repeat across time and individuals [101], have been shown to differ significantly in FTD patients compared to $\mathrm{AD}$, schizophrenia, and healthy controls [102].

Just recently, EEG abnormalities have been observed also in a group of genetic FTD patients. In particular, FTD due to $G R N$ mutations showed an increase in high $\alpha$ and decrease in $\theta$ oscillations as compared to non-carriers [103].

Other neurophysiological techniques, particularly transcranial magnetic stimulation (TMS), have become promising tools to assess specific cortical circuits in the central nervous system. In the context of dementia, different paired-pulse TMS paradigms have been implemented to assess intracortical inhibitory and excitatory interneuronal activity, namely short interval intracortical inhibition and facilitation (SICI-ICF), dependent on $\mathrm{GABA}_{\mathrm{A}}$ and glutamatergic transmission [104, 105], long-interval intracortical inhibition, dependent on $\mathrm{GABA}_{\mathrm{B}}$ transmission [106], and short-latency afferent inhibition (SAI), dependent on central cholinergic activity [107]. Furthermore, specific paradigms of paired associative stimulation [108] or repetitive TMS [109, 110] have shown to increase or decrease the excitability of corticospinal projections of the primary motor cortex (M1), representing a form of long-term potentiation or depression and thus a method of assessing synaptic plasticity.

Neurophysiological studies in FTD have shown central motor circuit abnormalities, even in cases without clinical evidence of motor involvement [10, 111-114]. No significant alterations in motor threshold [10, 112-116], SICI-ICF [112, 114], and SAI [111] have been observed in FTD [117, 118]. However, these studies have been hindered by the small number and by the selection of patients, which has been made exclusively on a clinical basis and not taking into account the significance of CSF proteins $\left(\mathrm{A} \beta_{42}\right.$, tTau, and pTau) to exclude possible focal variants of $\mathrm{AD}$, or the genetic contribution of known pathogenic mutations.

In this view, Burrell et al. have observed in a large cohort of 40 FTD patients, a significant decrease in SICI and a trend toward a reduced ICF, compared to 


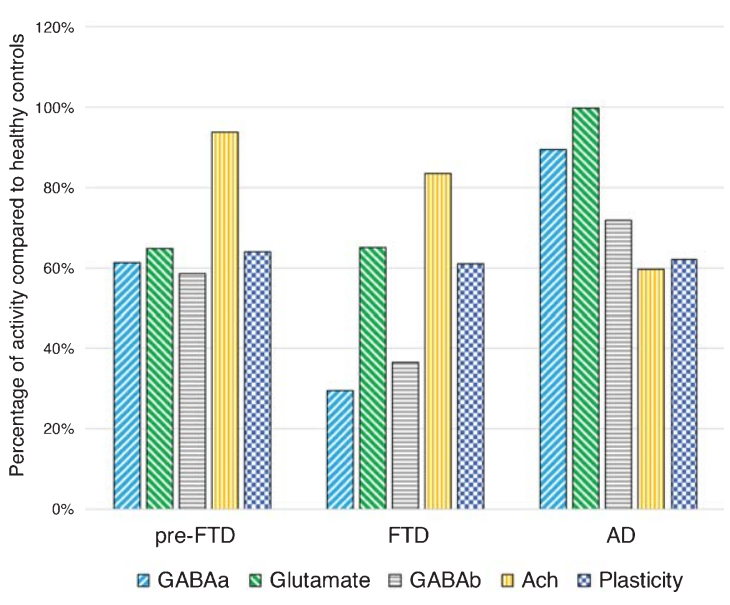

Fig. 3. Intracortical connectivity and LTP-like plasticity profiles in presymptomatic GRN carriers, in symptomatic FTD and AD patients, compared to healthy controls. Pre-FTD, presymptomatic granulin $(G R N)$ carriers; FTD, frontotemporal dementia patients; $\mathrm{AD}$, Alzheimer's disease patients; GABAa, GABA $\mathrm{A}_{\mathrm{A}}$ ergic activity evaluated with average short interval intracortical inhibition (1, 2, $3 \mathrm{~ms})$; Glutamate, glutamatergic activity evaluated with average intracortical facilitation $(7,10,15 \mathrm{~ms}) ; \mathrm{GABA}_{\mathrm{B}}, \mathrm{GABA}_{\mathrm{B}}$ ergic activity evaluated with average long interval intracortical inhibition $(50,100,150 \mathrm{~ms})$; Ach, cholinergic activity evaluated with average short latency afferent inhibition $\left({ }^{+} 0,{ }^{+} 4 \mathrm{~ms}\right)$; Plasticity, LTP-like plasticity evaluated with paired associative stimulation $\left(\right.$ mean $\left.{ }^{+} 10,{ }^{+} 20,{ }^{+} 30 \mathrm{~min}\right)$. Values are expressed as percentage of activity in healthy controls.

healthy controls [10]. These findings have been replicated in an even larger study on 64 FTD patients, in which a striking impairment of SICI-ICF was observed compared to $79 \mathrm{AD}$ patients and 32 healthy controls. Furthermore, as expected, an impairment of central cholinergic circuits evaluated with the SAI paradigm, was observed only in AD patients [119] (Fig. 3). Combining both measures of GABAergic and cholinergic transmission (SICI-ICF and SAI respectively), Benussi et al. determined the diagnostic accuracy of TMS to discriminate between AD, FTD, and healthy controls, with levels of sensitivity and specificity $>80-85 \%$, even in patients with a high biomarker confidence (CSF A $\beta_{42}$ and tau determination or amyloid PET imaging) and in the early phases of disease [119].

The impairment of intracortical inhibitory and excitatory circuits (SICI-ICF) has been observed also in a cohort of presymptomatic carriers and symptomatic patients bearing a pathogenic GRN mutation, with a progressive decline in GABAergic transmission in the symptomatic phases of disease. In addition, long-term potentiation-like cortical plasticity, assessed by the paired associative stimulation protocol, has been shown to be strikingly impaired in the presymptomatic phases of disease, at more than 18 years before expected symptom onset [17] (Fig. 3).

\section{CONCLUSIONS}

The field of biomarkers in FTD has made significant progress in the past few years and numerous studies have tried to shed light on the most significant issues in the realm of FTD. In the first place, the study of the earliest physiopathological modifications in FTD has gained much drive from the observations in presymptomatic carriers of known FTD gene mutations. Secondly, biomarkers have shown to increase the diagnostic accuracy of FTD, both between different diseases, as for $\mathrm{AD}$, and between different subtypes of FTD, as for FTLD-TDP and FTLD-Tau. Thirdly, the prognostic capacity has amply improved.

Taken together, these findings have led to major advances in the knowledge of FTD pathophysiology. However, a more profound integration of these biomarkers probably holds the key to unravel the most cunning issues in the realm of FTD, by investigating multiple interconnections between the domain of protein-opathies, connect-opathies, and neurotransmitter-opathies.

With a new emphasis on multi-modal approaches, the next years hold promise for even greater understanding of the physiopathology of FTD, with crucial implications for clinical management, diagnosis and therapeutic trials.

\section{DISCLOSURE STATEMENT}

Authors' disclosures available online (http://j-alz. com/manuscript-disclosures/17-0584r1).

\section{REFERENCES}

[1] The Lund and Manchester Groups (1994) Clinical and neuropathological criteria for frontotemporal dementia. The Lund and Manchester Groups. I Neurol Neurosurg Psychiatry 57, 416-418.

[2] Neary D, Snowden JS, Gustafson L, Passant U, Stuss D, Black S, Freedman M, Robert PH, Albert M, Boone K, Miller BL, Cummings J, Benson DF (1998) Frontotemporal lobar degeneration: A consensus on clinical diagnostic criteria. Neurology 51, 1546-1554.

[3] McKhann GM (2001) Clinical and pathological diagnosis of frontotemporal dementia. Arch Neurol 58, 1803.

[4] Seelaar H, Rohrer JD, Pijnenburg YAL, Fox NC, van Swieten JC (2011) Clinical, genetic and pathological heterogeneity of frontotemporal dementia: A review. J Neurol Neurosurg Psychiatry 82, 476-486. 
[5] Vieira RT, Caixeta L, Machado S, Silva AC, Nardi AE, Arias-Carrión O, Carta MG (2013) Epidemiology of earlyonset dementia: A review of the literature. Clin Pract Epidemiol Ment Health 9, 88-95.

[6] Borroni B, Turrone R, Galimberti D, Nacmias B, Alberici A, Benussi A, Caffarra P, Caltagirone C, Cappa SF, Frisoni GB, Ghidoni R, Marra C, Padovani A, Rainero I, Scarpini E, Silani V, Sorbi S, Tagliavini F, Tremolizzo L, Bruni AC, FTD Group-SINDEM (2015) Italian Frontotemporal Dementia Network (FTD GroupSINDEM): Sharing clinical and diagnostic procedures in Frontotemporal Dementia in Italy. Neurol Sci 36, 751-757.

[7] Rascovsky K, Hodges JR, Knopman D, Mendez MF, Kramer JH, Neuhaus J, van Swieten JC, Seelaar H, Dopper EGP, Onyike CU, Hillis AE, Josephs KA, Boeve BF, Kertesz A, Seeley WW, Rankin KP, Johnson JK, GornoTempini ML, Rosen H, Prioleau-Latham CE, Lee A, Kipps CM, Lillo P, Piguet O, Rohrer JD, Rossor MN, Warren JD, Fox NC, Galasko D, Salmon DP, Black SE, Mesulam MM, Weintraub S, Dickerson BC, Diehl-Schmid J, Pasquier F, Deramecourt V, Lebert F, Pijnenburg Y, Chow TW, Manes F, Grafman J, Cappa SF, Freedman M, Grossman M, Miller BL (2011) Sensitivity of revised diagnostic criteria for the behavioural variant of frontotemporal dementia. Brain 134, 2456-2477.

[8] Mesulam M-M (1982) Slowly progressive aphasia without generalized dementia. Ann Neurol 11, 592-598.

[9] Gorno-Tempini ML, Hillis AE, Weintraub S, Kertesz A, Mendez M, Cappa SF, Ogar JM, Rohrer JD, Black S, Boeve BF, Manes F, Dronkers NF, Vandenberghe R, Rascovsky K, Patterson K, Miller BL, Knopman DS, Hodges JR, Mesulam M-M, Grossman M (2011) Classification of primary progressive aphasia and its variants. Neurology 76, 1006-1014.

[10] Burrell JR, Kiernan MC, Vucic S, Hodges JR (2011) Motor Neuron dysfunction in frontotemporal dementia. Brain 134, 2582-2594.

[11] Lomen-Hoerth C, Anderson T, Miller B (2002) The overlap of amyotrophic lateral sclerosis and frontotemporal dementia. Neurology 59, 1077-1079.

[12] Armstrong MJ, Litvan I, Lang AE, Bak TH, Bhatia KP, Borroni B, Boxer AL, Dickson DW, Grossman M, Hallett M, Josephs KA, Kertesz A, Lee SE, Miller BL, Reich SG, Riley DE, Tolosa E, Tröster AI, Vidailhet M, Weiner WJ (2013) Criteria for the diagnosis of corticobasal degeneration. Neurology 80, 496-503.

[13] Benussi A, Padovani A, Borroni B (2015) Phenotypic heterogeneity of monogenic frontotemporal dementia. Front Aging Neurosci 7, 171.

[14] Alberici A, Benussi A, Premi E, Borroni B, Padovani A (2014) Clinical, genetic, and neuroimaging features of early onset Alzheimer disease: The challenges of diagnosis and treatment. Curr Alzheimer Res 11, 909-917.

[15] Padovani A, Borroni B, Premi E, Pilotto A, Gazzina S, Cosseddu M, Archetti S, Cancelli V, Paghera B (2013) Overlap between frontotemporal dementia and Alzheimer's disease: Cerebrospinal fluid pattern and neuroimaging study. J Alzheimers Dis 36, 49-55.

[16] Borroni B, Alberici A, Cercignani M, Premi E, Serra L, Cerini C, Cosseddu M, Pettenati C, Turla M, Archetti S, Gasparotti R, Caltagirone C, Padovani A, Bozzali M (2012) Granulin mutation drives brain damage and reorganization from preclinical to symptomatic FTLD. Neurobiol Aging 33, 2506-2520.
[17] Benussi A, Cosseddu M, Filareto I, Dell'Era V, Archetti S, Sofia Cotelli M, Micheli A, Padovani A, Borroni B (2016) Impaired long-term potentiation-like cortical plasticity in presymptomatic genetic frontotemporal dementia. Ann Neurol 80, 472-476.

[18] Rohrer JD, Nicholas JM, Cash DM, Van Swieten J, Dopper E, Jiskoot L, van Minkelen R, Rombouts SA, Cardoso MJ, Clegg S, Espak M, Mead S, Thomas DL, De Vita E, Masellis M, Black SE, Freedman M, Keren R, MacIntosh BJ, Rogaeva E, Tang-Wai D, Tartaglia MC, Laforce R, Tagliavini F, Tiraboschi P, Redaelli V, Prioni S, Grisoli M, Borroni B, Padovani A, Galimberti D, Scarpini E, Arighi A, Fumagalli G, Rowe JB, Coyle-Gilchrist I, Graff C, Fallström M, Jelic V, Ståhlbom AK, Andersson C, Thonberg H, Lilius L, Frisoni GB, Pievani M, Bocchetta M, Benussi L, Ghidoni R, Finger E, Sorbi S, Nacmias B, Lombardi G, Polito C, Warren JD, Ourselin S, Fox NC, Rossor MN, Binetti G (2015) Presymptomatic cognitive and neuroanatomical changes in genetic frontotemporal dementia in the Genetic Frontotemporal dementia Initiative (GENFI) study: A cross-sectional analysis. Lancet Neurol 14, 253-262.

[19] Hu WT, Watts K, Grossman M, Glass J, Lah JJ, Hales C, Shelnutt M, Van Deerlin V, Trojanowski JQ, Levey AI (2013) Reduced CSF p-Tau 181 to Tau ratio is a biomarker for FTLD-TDP. Neurology 81, 1945-1952.

[20] Grossman M, Elman L, McCluskey L, McMillan CT, Boller A, Powers J, Rascovsky K, Hu W, Shaw L, Irwin DJ, Lee VMY, Trojanowski JQ (2014) Phosphorylated tau as a candidate biomarker for amyotrophic lateral sclerosis. JAMA Neurol 71, 442.

[21] Borroni B, Benussi A, Archetti S, Galimberti D, Parnetti L, Nacmias B, Sorbi S, Scarpini E, Padovani A (2015) CSF p-tau181/tau ratio as biomarker for TDP pathology in frontotemporal dementia. Amyotroph Lateral Scler Frontotemporal Degener 16, 86-91.

[22] Borroni B, Benussi A, Cosseddu M, Archetti S, Padovani A (2014) Cerebrospinal fluid tau levels predict prognosis in non-inherited frontotemporal dementia. Neurodegener Dis 13, 224-229.

[23] Borroni B, Grassi M, Premi E, Alberici A, Cosseddu M, Cancelli V, Caobelli F, Paghera B, Padovani A (2012) Is long-term prognosis of frontotemporal lobar degeneration predictable by neuroimaging? Evidence from a single-subject functional brain study. J Alzheimers Dis $\mathbf{2 9}$, 883-890.

[24] Borroni B, Cerini C, Archetti S, Premi E, Cosseddu M, Ferrari M, Bellelli G, Gasparotti R, Caimi L, Di Luca M, Padovani A (2011) Cerebrospinal fluid tau in frontotemporal lobar degeneration: Clinical, neuroimaging, and prognostic correlates. J Alzheimers Dis 23, 505-512.

[25] Josephs KA (2008) Frontotemporal dementia and related disorders: Deciphering the enigma. Ann Neurol 64, 4-14.

[26] Grossman M (2010) Primary progressive aphasia: Clinicopathological correlations. Nat Rev Neurol 6, 88-97.

[27] Olsson B, Lautner R, Andreasson U, Öhrfelt A, Portelius E, Bjerke M, Hölttä M, Rosén C, Olsson C, Strobel G, Wu E, Dakin K, Petzold M, Blennow K, Zetterberg $\mathrm{H}$ (2016) CSF and blood biomarkers for the diagnosis of Alzheimer's disease: A systematic review and metaanalysis. Lancet Neurol 15, 673-684.

[28] Rivero-Santana A, Ferreira D, Perestelo-Pérez L, Westman E, Wahlund L-O, Sarría A, Serrano-Aguilar P (2017) Cerebrospinal fluid biomarkers for the differential diagnosis between Alzheimer's disease and frontotemporal lobar 
degeneration: Systematic review, HSROC analysis, and confounding factors. J Alzheimers Dis 55, 625-644.

[29] Struyfs H, Van Broeck B, Timmers M, Fransen E, Sleegers K, Van Broeckhoven C, De Deyn PP, Streffer JR, Mercken M, Engelborghs S (2015) Diagnostic accuracy of cerebrospinal fluid amyloid- $\beta$ isoforms for early and differential dementia diagnosis. J Alzheimers Dis 45, 813822.

[30] Janelidze S, Zetterberg H, Mattsson N, Palmqvist S, Vanderstichele H, Lindberg O, van Westen D, Stomrud E, Minthon L, Blennow K, the Swedish BioFINDER, study group, Hansson O (2016) CSF A $342 / A \beta 40$ and $A \beta 42 / A \beta 38$ ratios: Better diagnostic markers of Alzheimer disease. Ann Clin Transl Neurol 3, 154-165.

[31] Santangelo R, Coppi E, Ferrari L, Bernasconi MP, Pinto P, Passerini G, Comi G, Magnani G (2015) Cerebrospinal fluid biomarkers can play a pivotal role in the diagnostic work up of primary progressive aphasia. J Alzheimers Dis 43, 1429-1440.

[32] Teichmann M, Kas A, Boutet C, Ferrieux S, Nogues M, Samri D, Rogan C, Dormont D, Dubois B, Migliaccio R (2013) Deciphering logopenic primary progressive aphasia: A clinical, imaging and biomarker investigation. Brain 136, 3474-3488.

[33] Padovani A, Benussi A, Ferrari F, Archetti S, Borroni B (2012) Prevalence of cerebrospinal fluid Alzheimer disease-like pattern in atypical dementias. Adv Alzheimers Dis 1, 45-50.

[34] Oboudiyat C, Gefen T, Varelas E, Weintraub S, Rogalski E, Bigio EH, Mesulam MM (2017) Cerebrospinal fluid markers detect Alzheimer's disease in nonamnestic dementia. Alzheimers Dement 13, 598-601.

[35] Junttila A, Kuvaja M, Hartikainen P, Siloaho M, Helisalmi S, Moilanen V, Kiviharju A, Jansson L, Tienari PJ, Remes AM, Herukka SK (2016) Cerebrospinal fluid TDP-43 in frontotemporal lobar degeneration and amyotrophic lateral sclerosis patients with and without the C9ORF72 hexanucleotide expansion. Dement Geriatr Cogn Disord Extra 6, 142-149.

[36] Steinacker P, Hendrich C, Sperfeld AD, Jesse S, Arnim von CAF, Lehnert S, Pabst A, Uttner I, Tumani H, Lee VMY, Trojanowski JQ, Kretzschmar HA, Ludolph A, Neumann M, Otto M (2008) TDP-43 in cerebrospinal fluid of patients with frontotemporal lobar degeneration and amyotrophic lateral sclerosis. Arch Neurol 65, 1481-1487.

[37] Pijnenburg YAL, Verwey NA, van der Flier WM, Scheltens P, Teunissen CE (2015) Discriminative and prognostic potential of cerebrospinal fluid phosphoTau/tau ratio and neurofilaments for frontotemporal dementia subtypes. Alzheimers Dement (Amst) 1, 505-512.

[38] Suarez-Calvet M, Dols-Icardo O, Lladó A, Sánchez-Valle R, Hernandez I, Amer G, Anton-Aguirre S, Alcolea D, Fortea J, Ferrer I, van der Zee J, Dillen L, Van Broeckhoven C, Molinuevo JL, Blesa R, Clarimon J, Lleó A (2014) Plasma phosphorylated TDP-43 levels are elevated in patients with frontotemporal dementia carrying a C9orf72 repeat expansion or a GRN mutation. J Neurol Neurosurg Psychiatry 85, 684-691.

[39] Spillantini MG, Goedert M (2013) Tau pathology and neurodegeneration. Lancet Neurol 12, 609-622.

[40] Wang J-Z, Grundke-Iqbal I, Iqbal K (2007) Kinases and phosphatases and tau sites involved in Alzheimer neurofibrillary degeneration. Eur J Neurosci 25, 59-68.

[41] Wray S, Saxton M, Anderton BH, Hanger DP (2008) Direct analysis of tau from PSP brain identifies new phosphorylation sites and a major fragment of $\mathrm{N}$-terminally cleaved tau containing four microtubulebinding repeats. J Neurochem 105, 2343-2352.

[42] Borroni B, Malinverno M, Gardoni F, Alberici A, Parnetti L, Premi E, Bonuccelli U, Grassi M, Perani D, Calabresi P, Di Luca M, Padovani A (2008) Tau forms in CSF as a reliable biomarker for progressive supranuclear palsy. Neurology 71, 1796-1803.

[43] Borroni B, Padovani A, Gardoni F, Parnetti L, Magno L, Malinverno M, Saggese E, Calabresi P, Spillantini MG, Di Luca M (2009) Pattern of tau forms in CSF is altered in progressive supranuclear palsy. Neurobiol Aging 30, 3440.

[44] Wagshal D, Sankaranarayanan S, Guss V, Hall T, Berisha F, Lobach I, Karydas A, Voltarelli L, Scherling C, Heuer H, Tartaglia MC, Miller Z, Coppola G, Ahlijanian M, Soares H, Kramer JH, Rabinovici GD, Rosen HJ, Miller BL, Meredith J, Boxer AL (2015) Divergent CSF $\tau$ alterations in two common tauopathies: Alzheimer's disease and progressive supranuclear palsy. J Neurol Neurosurg Psychiatry 86, 244-250.

[45] Arai T, Ikeda K, Akiyama H, Nonaka T, Hasegawa M, Ishiguro K, Iritani S, Tsuchiya K, Iseki E, Yagishita S, Oda T, Mochizuki A (2003) Identification of amino-terminally cleaved tau fragments that distinguish progressive supranuclear palsy from corticobasal degeneration. Ann Neurol 55, 72-79.

[46] Meeter LH, Dopper EG, Jiskoot LC, Sanchez-Valle R, Graff C, Benussi L, Ghidoni R, Pijnenburg YA, Borroni B, Galimberti D, Laforce RJ, Masellis M, Vandenberghe R, Ber IL, Otto M, van Minkelen R, Papma JM, Rombouts SA, Balasa M, Öijerstedt L, Jelic V, Dick KM, Cash DM, Harding SR, Jorge Cardoso M, Ourselin S, Rossor MN, Padovani A, Scarpini E, Fenoglio C, Tartaglia MC, Lamari F, Barro C, Kuhle J, Rohrer JD, Teunissen CE, van Swieten JC (2016) Neurofilament light chain: A biomarker for genetic frontotemporal dementia. Ann Clin Transl Neurol 3, 623-636.

[47] Scherling CS, Hall T, Berisha F, Klepac K, Karydas A, Coppola G, Kramer JH, Rabinovici G, Ahlijanian M, Miller BL, Seeley W, Grinberg LT, Rosen H, Meredith J, Boxer AL (2014) Cerebrospinal fluid neurofilament concentration reflects disease severity in frontotemporal degeneration. Ann Neurol 75, 116-126.

[48] Rohrer JD, Woollacott IOC, Dick KM, Brotherhood E, Gordon E, Fellows A, Toombs J, Druyeh R, Cardoso MJ, Ourselin S, Nicholas JM, Norgren N, Mead S, Andreasson U, Blennow K, Schott JM, Fox NC, Warren JD, Zetterberg $H$ (2016) Serum neurofilament light chain protein is a measure of disease intensity in frontotemporal dementia. Neurology 87, 1329-1336.

[49] Landqvist Waldö M, Frizell Santillo A, Passant U, Zetterberg H, Rosengren L, Nilsson C, Englund E (2013) Cerebrospinal fluid neurofilament light chain protein levels in subtypes of frontotemporal dementia. BMC Neurol 13, 54 .

[50] Lu C-H, Macdonald-Wallis C, Gray E, Pearce N, Petzold A, Norgren N, Giovannoni G, Fratta P, Sidle K, Fish M, Orrell R, Howard R, Talbot K, Greensmith L, Kuhle J, Turner MR, Malaspina A (2015) Neurofilament light chain: A prognostic biomarker in amyotrophic lateral sclerosis. Neurology 84, 2247-2257.

[51] Hansson O, Janelidze S, Hall S, Magdalinou N, Lees AJ, Andreasson U, Norgren N, Linder J, Forsgren L, Constantinescu R, Zetterberg H, Blennow K (2017) Blood-based 
NfL: A biomarker for differential diagnosis of parkinsonian disorder. Neurology 88, 930-937.

[52] Agosta F, Caso F, Filippi M (2012) Dementia and neuroimaging. J Neurol 260, 685-691.

[53] Whitwell JL, Avula R, Senjem ML, Kantarci K, Weigand SD, Samikoglu A, Edmonson HA, Vemuri P, Knopman DS, Boeve BF, Petersen RC, Josephs KA, Jack CR (2010) Gray and white matter water diffusion in the syndromic variants of frontotemporal dementia. Neurology 74, 12791287.

[54] Borroni B, Brambati SM, Agosti C, Gipponi S, Bellelli G, Gasparotti R, Garibotto V, Di Luca M, Scifo P, Perani D, Padovani A (2007) Evidence of white matter changes on diffusion tensor imaging in frontotemporal dementia. Arch Neurol 64, 246-251.

[55] Lu PH, Mendez MF, Lee GJ, Leow AD, Lee H-W, Shapira J, Jimenez E, Boeve BB, Caselli RJ, Graff-Radford NR, Jack CR, Kramer JH, Miller BL, Bartzokis G, Thompson PM, Knopman DS (2013) Patterns of brain atrophy in clinical variants of frontotemporal lobar degeneration. Dement Geriatr Cogn Disord 35, 34-50.

[56] Whitwell JL, Weigand SD, Boeve BF, Senjem ML, Gunter JL, DeJesus-Hernandez M, Rutherford NJ, Baker M, Knopman DS, Wszolek ZK, Parisi JE, Dickson DW, Petersen RC, Rademakers R, Jack CR, Josephs KA (2012) Neuroimaging signatures of frontotemporal dementia genetics: C9ORF72, tau, progranulin and sporadics. Brain 135, 794-806.

[57] Devenney E, Hornberger M, Irish M, Mioshi E, Burrell J, Tan R, Kiernan MC, Hodges JR (2014) Frontotemporal dementia associated with the C9ORF72 mutation. JAMA Neurol 71, 331.

[58] Luis E, Ortiz A, Eudave L, Ortega-Cubero S, Borroni B, van der Zee J, Gazzina S, Caroppo P, Rubino E, D'Agata F, Le Ber I, Santana I, Cunha G, Almeida $\mathrm{MR}$, Boutoleau-Bretonnière $\mathrm{C}$, Hannequin $\mathrm{D}$, Wallon $\mathrm{D}$, Rainero I, Galimberti D, Van Broeckhoven C, Pastor MA, Pastor P (2016) Neuroimaging correlates of frontotemporal dementia associated with SQSTM1 mutations. J Alzheimers Dis 53, 303-313.

[59] Gordon E, Rohrer JD, Kim LG, Omar R, Rossor MN, Fox NC, Warren JD (2010) Measuring disease progression in frontotemporal lobar degeneration: A clinical and MRI study. Neurology 74, 666-673.

[60] Premi E, Gualeni V, Costa P, Cosseddu M, Gasparotti R, Padovani A, Borroni B (2016) Looking for measures of disease severity in the frontotemporal dementia continuum. J Alzheimers Dis 52, 1227-1235.

[61] Rohrer JD, Clarkson MJ, Kittus R, Rossor MN, Ourselin S, Warren JD, Fox NC (2012) Rates of hemispheric and lobar atrophy in the language variants of frontotemporal lobar degeneration. J Alzheimers Dis 30, 407-411.

[62] Whitwell JL, Jack CR Jr, Pankratz VS, Parisi JE, Knopman DS, Boeve BF, Petersen RC, Dickson DW, Josephs KA (2008) Rates of brain atrophy over time in autopsyproven frontotemporal dementia and Alzheimer disease. Neuroimage 39, 1034-1040.

[63] Harper L, Fumagalli GG, Barkhof F, Scheltens P, O'Brien JT, Bouwman F, Burton EJ, Rohrer JD, Fox NC, Ridgway GR, Schott JM (2016) MRI visual rating scales in the diagnosis of dementia: Evaluation in 184 post-mortem confirmed cases. Brain 139(Pt 4), 1211-1225.

[64] Kipps CM, Davies RR, Mitchell J, Kril JJ, Halliday GM, Hodges JR (2007) Clinical significance of lobar atrophy in frontotemporal dementia: Application of an MRI visual rating scale. Dement Geriatr Cogn Disord 23, 334-342.

[65] Borroni B, Malinverno M, Gardoni F, Grassi M, Parnetti L, Agosti C, Alberici A, Premi E, Bonuccelli U, Gasparotti R, Calabresi P, Di Luca M, Padovani A (2010) A combination of CSF tau ratio and midsaggital midbrain-to-pons atrophy for the early diagnosis of progressive supranuclear palsy. J Alzheimers Dis 22, 195-203.

[66] Borroni B, Alberici A, Premi E, Archetti S, Garibotto V, Agosti C, Gasparotti R, Di Luca M, Perani D, Padovani A (2008) Brain magnetic resonance imaging structural changes in a pedigree of asymptomatic progranulin mutation carriers. Rejuvenation Res 11, 585-595.

[67] Pievani M, Filippini N, van den Heuvel MP, Cappa SF, Frisoni GB (2014) Brain connectivity in neurodegenerative diseases-from phenotype to proteinopathy. Nat Rev Neurol 10, 620-633.

[68] Premi E, Borroni B, Formenti A, Gazzina S, Archetti S, Gasparotti R, Padovani A (2013) Effect of TMEM106B polymorphism on functional network connectivity in asymptomatic GRN mutation carriers. JAMA Neurol 71, 216-221.

[69] Premi E, Cauda F, Gasparotti R, Diano M, Archetti S, Padovani A, Borroni B (2014) Multimodal fMRI restingstate functional connectivity in granulin mutations: The case of fronto-parietal dementia. PLoS One 9, e106500.

[70] Dopper EGP, Rombouts SARB, Jiskoot LC, Heijer den T, de Graaf JRA, de Koning I, Hammerschlag AR, Seelaar H, Seeley WW, Veer IM, Van Buchem MA, Rizzu P, van Swieten JC (2014) Structural and functional brain connectivity in presymptomatic familial frontotemporal dementia. Neurology 83, e19-e26.

[71] Zhou J, Greicius MD, Gennatas ED, Growdon ME, Jang JY, Rabinovici GD, Kramer JH, Weiner M, Miller BL, Seeley WW (2010) Divergent network connectivity changes in behavioural variant frontotemporal dementia and Alzheimer's disease. Brain 133, 1352-1367.

[72] Hafkemeijer A, Möller C, Dopper EGP, Jiskoot LC, van den Berg-Huysmans AA, van Swieten JC, van der Flier WM, Vrenken H, Pijnenburg YAL, Barkhof F, Scheltens P, van der Grond J, Rombouts SARB (2017) A longitudinal study on resting state functional connectivity in behavioral variant frontotemporal dementia and Alzheimer's disease. J Alzheimers Dis 55, 521-537.

[73] Lee SE, Khazenzon AM, Trujillo AJ, Guo CC, Yokoyama JS, Sha SJ, Takada LT, Karydas AM, Block NR, Coppola G, Pribadi M, Geschwind DH, Rademakers R, Fong JC, Weiner MW, Boxer AL, Kramer JH, Rosen HJ, Miller BL, Seeley WW (2014) Altered network connectivity in frontotemporal dementia with C9orf72 hexanucleotide repeat expansion. Brain 137, 3047-3060.

[74] Zhou J, Seeley WW (2014) Network dysfunction in Alzheimer's disease and frontotemporal dementia: Implications for psychiatry. Biol Psychiatry 75, 565-573.

[75] Agosta F, Sala S, Valsasina P, Meani A, Canu E, Magnani G, Cappa SF, Scola E, Quatto P, Horsfield MA, Falini A, Comi G, Filippi M (2013) Brain network connectivity assessed using graph theory in frontotemporal dementia. Neurology 81, 134-143.

[76] Sedeño L, Piguet O, Abrevaya S, Desmaras H, GarcíaCordero I, Baez S, Alethia de la Fuente L, Reyes P, Tu S, Moguilner S, Lori N, Landin-Romero R, Matallana D, Slachevsky A, Torralva T, Chialvo D, Kumfor F, García AM, Manes F, Hodges JR, Ibanez A (2017) Tackling variability: A multicenter study to provide a gold- 
standard network approach for frontotemporal dementia. Hum Brain Mapp 38, 3804-3822.

[77] Premi E, Cauda F, Costa T, Diano M, Gazzina S, Gualeni V, Alberici A, Archetti S, Magoni M, Gasparotti R, Padovani A, Borroni B (2016) Looking for neuroimaging markers in frontotemporal lobar degeneration clinical trials: A multi-voxel pattern analysis study in granulin disease. J Alzheimers Dis 51, 249-262.

[78] Zou Q-H, Zhu C-Z, Yang Y, Zuo X-N, Long X-Y, Cao Q-J, Wang Y-F, Zang Y-F (2008) An improved approach to detection of amplitude of low-frequency fluctuation (ALFF) for resting-state fMRI: Fractional ALFF. J Neurosci Methods 172, 137-141.

[79] Buckner RL, Sepulcre J, Talukdar T, Krienen FM, Liu H, Hedden T, Andrews-Hanna JR, Sperling RA, Johnson KA (2009) Cortical hubs revealed by intrinsic functional connectivity: Mapping, assessment of stability, and relation to Alzheimer's disease. J Neurosci 29, 1860-1873.

[80] Salmon E, Garraux G, Delbeuck X, Collette F, Kalbe E, Zuendorf G, Perani D, Fazio F, Herholz K (2003) Predominant ventromedial frontopolar metabolic impairment in frontotemporal dementia. Neuroimage 20, 435-440.

[81] Kanda T, Ishii K, Uemura T, Miyamoto N, Yoshikawa T, Kono AK, Mori E (2008) Comparison of grey matter and metabolic reductions in frontotemporal dementia using FDG-PET and voxel-based morphometric MR studies. Eur J Nucl Med Mol Imaging 35, 2227-2234.

[82] Cerami C, Dodich A, Greco L, Iannaccone S, Magnani G, Marcone A, Pelagallo E, Santangelo R, Cappa SF, Perani D (2017) The role of single-subject brain metabolic patterns in the early differential diagnosis of primary progressive aphasias and in prediction of progression to dementia. $J$ Alzheimers Dis 55, 183-197.

[83] Taswell C, Villemagne VL, Yates P, Shimada H, Leyton CE, Ballard KJ, Piguet O, Burrell JR, Hodges JR, Rowe CC (2015) 18F-FDG PET improves diagnosis in patients with focal-onset dementias. J Nucl Med 56, 1547-1553.

[84] Foster NL, Heidebrink JL, Clark CM, Jagust WJ, Arnold SE, Barbas NR, DeCarli CS, Scott Turner R, Koeppe RA, Higdon R, Minoshima S (2007) FDG-PET improves accuracy in distinguishing frontotemporal dementia and Alzheimer's disease. Brain 130, 2616-2635.

[85] Perani D, Rosa Della PA, Cerami C, Gallivanone F, Fallanca F, Vanoli EG, Panzacchi A, Nobili F, Pappatà S, Marcone A, Garibotto V, Castiglioni I, Magnani G, Cappa SF, Gianolli L, EADC-PET Consortium (2014) Validation of an optimized SPM procedure for FDG-PET in dementia diagnosis in a clinical setting. Neuroimage Clin 6, 445-454.

[86] Hall B, Mak E, Cervenka S, Aigbirhio FI, Rowe JB, O'Brien JT (2017) In vivo tau PET imaging in dementia: Pathophysiology, radiotracer quantification, and a systematic review of clinical findings. Ageing Res Rev 36, 50-63.

[87] Villemagne VL, Fodero-Tavoletti MT, Masters CL, Rowe CC (2015) Tau imaging: Early progress and future directions. Lancet Neurol 14, 114-124.

[88] Xia C-F, Arteaga J, Chen G, Gangadharmath U, Gomez LF, Kasi D, Lam C, Liang Q, Liu C, Mocharla VP, Mu F, Sinha A, Su H, Szardenings AK, Walsh JC, Wang E, Yu C, Zhang W, Zhao T, Kolb HC (2013) [18F]T807, a novel tau positron emission tomography imaging agent for Alzheimer's disease. Alzheimers Dement 9, 666-676.

[89] Maruyama M, Shimada H, Suhara T, Shinotoh H, Ji B, Maeda J, Zhang M-R, Trojanowski JQ, Lee VMY, Ono M, Masamoto K, Takano H, Sahara N, Iwata N, Okamura
N, Furumoto S, Kudo Y, Chang Q, Saido TC, Takashima A, Lewis J, Jang M-K, Aoki I, Ito H, Higuchi M (2013) Imaging of tau pathology in a tauopathy mouse model and in Alzheimer patients compared to normal controls. Neuron 79, 1094-1108.

[90] Smith R, Puschmann A, Schöll M, Ohlsson T, Van Swieten J, Honer M, Englund E, Hansson O (2016) 18F-AV-1451 tau PET imaging correlates strongly with tau neuropathology in MAPTmutation carriers. Brain 139, 2372-2379.

[91] Spina S, Schonhaut DR, Boeve BF, Seeley WW, Ossenkoppele R, O’Neil JP, Lazaris A, Rosen HJ, Boxer AL, Perry DC, Miller BL, Dickson DW, Parisi JE, Jagust WJ, Murray ME, Rabinovici GD (2017) Frontotemporal dementia with the V337M MAPTmutation. Neurology 88, 758-766.

[92] Tan RH, Kril JJ, Yang Y, Tom N, Hodges JR, Villemagne VL, Rowe CC, Leyton CE, Kwok JBJ, Ittner LM, Halliday GM (2017) Assessment of amyloid $\beta$ in pathologically confirmed frontotemporal dementia syndromes. Alzheimers Dement (Amst) 9, 10-20.

[93] Johannesson G, Hagberg B, Gustafson L, Ingvar DH (1979) EEG and cognitive impairment in presenile dementia. Acta Neurol Scand 59, 225-240.

[94] Rosén I, Gustafson L, Risberg J (1993) Multichannel EEG frequency analysis and somatosensory-evoked potentials in patients with different types of organic dementia. Dement Geriatr Cogn Disord 4, 43-49.

[95] Chan D, Walters RJ, Sampson EL, Schott JM, Smith SJ, Rossor MN (2004) EEG abnormalities in frontotemporal lobar degeneration. Neurology 62, 1628-1630.

[96] Lindau M, Jelic V, Johansson SE, Andersen C, Wahlund LO, Almkvist O (2003) Quantitative EEG abnormalities and cognitive dysfunctions in frontotemporal dementia and Alzheimer's disease. Dement Geriatr Cogn Disord 15, 106-114.

[97] Passant U, Rosén I, Gustafson L, Englund E (2005) The heterogeneity of frontotemporal dementia with regard to initial symptoms, qEEG and neuropathology. Int J Geriatr Psychiatry 20, 983-988.

[98] Yener GG, Leuchter AF, Jenden D, Read SL, Cummings JL, Miller BL (1996) Quantitative EEG in frontotemporal dementia. Clin Electroencephalogry 27, 61-68.

[99] Nishida K, Yoshimura M, Isotani T, Yoshida T, Kitaura Y, Saito A, Mii H, Kato M, Takekita Y, Suwa A, Morita S, Kinoshita T (2011) Differences in quantitative EEG between frontotemporal dementia and Alzheimer's disease as revealed by LORETA. Clin Neurophysiol 122, 1718-1725.

[100] Caso F, Cursi M, Magnani G, Fanelli G, Falautano M, Comi G, Leocani L, Minicucci F (2012) Quantitative EEG and LORETA: Valuable tools in discerning FTD from AD? Neurobiol Aging 33, 2343-2356.

[101] Khanna A, Pascual-Leone A, Michel CM, Farzan F (2015) Microstates in resting-state EEG: Current status and future directions. Neurosci Biobehav Rev 49, 105-113.

[102] Nishida K, Morishima Y, Yoshimura M, Isotani T, Irisawa S, Jann K, Dierks T, Strik W, Kinoshita T, Koenig T (2013) EEG microstates associated with salience and frontoparietal networks in frontotemporal dementia, schizophrenia and Alzheimer's disease. Clin Neurophysiol 124, 11061114.

[103] Moretti DV, Benussi L, Fostinelli S, Ciani M, Binetti G, Ghidoni R (2016) Progranulin mutations affects brain oscillatory activity in fronto-temporal dementia. Front Aging Neurosci 8, 311. 
[104] Kujirai T, Caramia MD, Rothwell JC, Day BL, Thompson PD, Ferbert A, Wroe S, Asselman P, Marsden CD (1993) Corticocortical inhibition in human motor cortex. J Physiol 471, 501-519.

[105] Ziemann U, Rothwell JC, Ridding MC (1996) Interaction between intracortical inhibition and facilitation in human motor cortex. J Physiol 496, 873-881.

[106] McDonnell MN, Orekhov Y, Ziemann U (2006) The role of GABAB receptors in intracortical inhibition in the human motor cortex. Exp Brain Res 173, 86-93.

[107] Di Lazzaro V, Oliviero A, Tonali PA, Marra C, Daniele A, Profice P, Saturno E, Pilato F, Masullo C, Rothwell JC (2002) Noninvasive in vivo assessment of cholinergic cortical circuits in $\mathrm{AD}$ using transcranial magnetic stimulation. Neurology 59, 392-397.

[108] Stefan K, Kunesch E, Cohen LG, Benecke R, Classen J (2000) Induction of plasticity in the human motor cortex by paired associative stimulation. Brain 123, 572-584.

[109] Fitzgerald PB, Fountain S, Daskalakis ZJ (2006) A comprehensive review of the effects of rTMS on motor cortical excitability and inhibition. Clin Neurophysiol 117, 25842596.

[110] Thut G, Pascual-Leone A (2009) A review of combined TMS-EEG studies to characterize lasting effects of repetitive TMS and assess their usefulness in cognitive and clinical neuroscience. Brain Topogr 22, 219-232.

[111] Di Lazzaro V, Pilato F, Dileone M, Saturno E, Oliviero A, Marra C, Daniele A, Ranieri F, Gainotti G, Tonali PA (2006) In vivo cholinergic circuit evaluation in frontotemporal and Alzheimer dementias. Neurology 66, 1111-1113.

[112] Alberici A, Bonato C, Calabria M, Agosti C, Zanetti O, Miniussi C, Padovani A, Rossini PM, Borroni B (2008) The contribution of TMS to frontotemporal dementia variants. Acta Neurol Scand 118, 275-280.
[113] Issac TG, Chandra SR, Nagaraju BC (2013) Transcranial magnetic stimulation in patients with early cortical dementia: A pilot study. Ann Indian Acad Neurol 16, 619-622.

[114] Pierantozzi M, Panella M, Palmieri MG, Koch G, Giordano A, Marciani MG, Bernardi G, Stanzione P, Stefani A (2004) Different TMS patterns of intracortical inhibition in early onset Alzheimer dementia and frontotemporal dementia. Clin Neurophysiol 115, 2410-2418.

[115] Di Lazzaro V, Pilato F, Oliviero A, Dileone M, Saturno E, Mazzone P, Insola A, Profice P, Ranieri F, Capone F, Tonali PA, Rothwell JC (2006) Origin of facilitation of motor-evoked potentials after paired magnetic stimulation: Direct recording of epidural activity in conscious humans. J Neurophysiol 96, 1765-1771.

[116] Wang P, Zhang H, Han L, Zhou Y (2016) Cortical function in Alzheimer's disease and frontotemporal dementia. Transl Neurosci 7, 116-125.

[117] Benussi A, Padovani A, Borroni B (2015) Transcranial magnetic stimulation in Alzheimer's disease and cortical dementias. J Alzheimers Dis Parkinsonism 5, 197.

[118] Cantone M, Di Pino G, Capone F, Piombo M, Chiarello D, Cheeran B, Pennisi G, Di Lazzaro V (2014) The contribution of transcranial magnetic stimulation in the diagnosis and in the management of dementia. Clin Neurophysiol 125, 1509-1532.

[119] Benussi A, Di Lorenzo F, Dell'Era V, Cosseddu M, Alberici A, Caratozzolo S, Cotelli MS, Micheli A, Rozzini L, Depari A, Flammini A, Ponzo V, Martorana A, Caltagirone C, Padovani A, Koch G, Borroni B (2017) Transcranial magnetic stimulation distinguishes Alzheimer's disease from frontotemporal dementia. $\mathrm{Neu}$ rology 2017, 1-8. 